THE CHURCH OF

SAINT THOMAS PAINE 



\section{The Church of}

\section{Saint Thomas Paine}

A RELIGIOUS HISTORY

OF AMERICAN SECULARISM

\section{LEIGH ERIC SCHMIDT}




\section{Copyright (C) 2021 by Princeton University Press}

Princeton University Press is committed to the protection of copyright and the intellectual property our authors entrust to us. Copyright promotes the progress and integrity of knowledge. Thank you for supporting free speech and the global exchange of ideas by purchasing an authorized edition of this book. If you wish to reproduce or distribute any part of it in any form, please obtain permission.

Requests for permission to reproduce material from this work should be sent to permissions@press.princeton.edu

Published by Princeton University Press

41 William Street, Princeton, New Jersey o8540

6 Oxford Street, Woodstock, Oxfordshire OX20 1TR

press.princeton.edu

All Rights Reserved

Library of Congress Cataloging-in-Publication Data

Names: Schmidt, Leigh Eric, author.

Title: The church of Saint Thomas Paine : a religious history of American secularism / Leigh Eric Schmidt.

Description: Princeton : Princeton University Press, 2021. | Includes bibliographical references and index.

Identifiers: LCCN 2021022302 | ISBN 9780691217253 (hardback) | ISBN 9780691217260 (ebook)

Subjects: LCSH: Secularism—United States—History. | United States-Religion—History. | Paine, Thomas, 1737-1809Religion. | BISAC: HISTORY / United States / Revolutionary Period (1775-1800) | BIOGRAPHY \& AUTOBIOGRAPHY / Historical

Classification: LCC BL2760.S36 2021 | DDC 211/.60973-dc23

LC record available at https://lccn.loc.gov/2021022302

British Library Cataloging-in-Publication Data is available

Editorial: Fred Appel and James Collier Production Editorial: Debbie Tegarden Text and Jacket Design: Karl Spurzem Production: Erin Suydam Publicity: Maria Whelan and Kathryn Stevens Copyeditor: Gail K. Schmitt

Jacket image: Portrait of Thomas Paine by William Sharp, engraver, and George Romney / Romney pinxt.; W. Sharp sculpt. United States, 1793. London: Published by W. Sharp, No. 8 Charles Street Middx. Hospt. Courtesy of the Library of Congress.

This book has been composed in Arno

Printed on acid-free paper. $\infty$

Printed in the United States of America

$\begin{array}{llllllllll}10 & 9 & 8 & 7 & 6 & 5 & 4 & 3 & 2 & 1\end{array}$ 